\title{
Metastatic basal cell carcinoma exhibits reduced actin expression
}

\author{
Maria C Uzquiano, Victor G Prieto, Jason W Nash, Doina S Ivan, Yun Gong, \\ Alexander JF Lazar and A Hafeez Diwan \\ Department of Pathology, UT MD Anderson Cancer Center, Houston, TX, USA
}

\begin{abstract}
Basal cell carcinoma is the most common malignancy in Caucasian individuals. Metastatic basal cell carcinoma is extremely rare (with a rate estimated as $0.03 \%$ ). Actin has been detected in aggressive forms of basal cell carcinoma, but their expression in metastatic lesions is not known. We compared the expression of actin and actin-related cytoskeletal proteins in relatively less aggressive basal cell carcinoma (nodular), aggressive basal cell carcinoma (infiltrative/morpheaform), and metastatic basal cell carcinoma. We studied 12 cases of nodular basal cell carcinoma, 10 cases of infiltrative basal cell carcinoma, and 10 cases of metastatic basal cell carcinoma with immunohistochemistry for alpha-smooth muscle actin, calponin, myosin, and E-cadherin. Expression was interpreted as positive when at least $5 \%$ of the tumor exhibited at least weak expression. Five of the ten patients with metastatic basal cell carcinoma had an antecedent history of radiotherapy. Actin was present in 3 of $12(25 \%)$ of the nodular, all 10 of the infiltrative, and 3 of 10 of the metastatic basal cell carcinomas $(\boldsymbol{P}<\mathbf{0 . 0 5}$ for metastatic vs infiltrative and nodular vs infiltrative). Calponin was present in $\mathbf{5 0 \%}$ of the nodular, $60 \%$ of the infiltrative, and $30 \%$ of the metastatic basal cell carcinomas (not statistically significant). Myosin expression was not detected in any of the cases. E-cadherin was present in $75 \%$ of the nodular, $70 \%$ of the infiltrative, and all of the metastatic basal cell carcinomas $(P<0.05$ for metastatic vs nodular). Our results suggest that increased actin may contribute to local invasiveness, but it is lost in the metastatic phenotype. History of previous radiotherapy may contribute to development of the metastatic phenotype.
\end{abstract}

Modern Pathology (2008) 21, 540-543; doi:10.1038/modpathol.3801051; published online 25 January 2008

Keywords: metastasis; actin; basal cell carcinoma

Basal cell carcinoma is the most common malignancy in Caucasian individuals. ${ }^{1}$ Despite this high incidence, metastatic basal cell carcinoma is extremely rare, with most recent studies suggesting that the rate is approximately $0.03 \% .^{2}$ Many of the reported cases have involved recurrent tumors or aggressive histological subtypes. Nearly $85 \%$ of all metastasizing basal cell carcinomas involve the head and neck region. ${ }^{3}$ Metastatic spread is most often to the regional lymph nodes followed in descending order by the lungs, bones, and skin. ${ }^{4} \mathrm{~A}$ review of 170 published cases of metastatic basal cell carcinoma showed a twofold male predilection, an average age of primary onset at 45 years, and a 9-year median interval to metastasis. ${ }^{5}$ Risk factors for metastatic basal cell carcinoma include persistent tumor for many years, previous radiation and large

Correspondence: Dr AH Diwan, MD, PhD, Department of Pathology, UT MD Anderson Cancer Center, 1515 Holcombe Blvd, Unit 85, Houston, TX 77030, USA.

E-mail: ahdiwan@mdanderson.org

Received 15 October 2007; revised 02 December 2007; accepted 03 December 2007; published online 25 January 2008 tumor size with a rate of $1.9 \%$ in tumors over $3 \mathrm{~cm}$ in diameter, nearly $50 \%$ for tumors over $10 \mathrm{~cm}$ in diameter, and $100 \%$ in tumors $>400 \mathrm{~cm}^{2}$ (ref. 4). Metastatic disease carries a poor prognosis with mean survival ranging from 8 months to 3.6 years. $^{5}$

One of the characteristics of malignancy is invasion. Cytoskeletal reorganizations, especially alterations of contractile tension generated by the actin-myosin complex, are of central importance in the development of the phenotype of morphologically transformed neoplastic cells with invasive behavior. Actin ${ }^{6-9}$ and calponin ${ }^{10,11}$ may be associated with increased contractility and invasiveness of tumor cells, and both have been identified in infiltrative basal cell carcinoma. ${ }^{9,10}$ In contrast, E-cadherin may serve to counteract the invasiveness of basal cell carcinoma. ${ }^{12}$ The role of myosin, if any, has not been evaluated in basal cell carcinoma.

In our study, we evaluate the roles of actin, calponin, myosin, and E-cadherin in metastatic as compared to nodular and infiltrative basal cell carcinoma. 


\section{Materials and methods}

Using an IRB-approved protocol, the files of UT MD Anderson Cancer Center, formalin-fixed, paraffinembedded tissues were obtained from 12 cases of nodular, 10 cases of infiltrative, and 10 cases of metastatic basal cell carcinomas. We performed immunohistochemistry on each of these cases with monoclonal antibodies against smooth muscle actin (clone1A4, Sigma, St Louis, MO), E-cadherin (mouse monoclonal antibody (HECD-1) specific for human E-CD, Zymed, Invitrogen, South, San Francisco, CA), myosin (My-32, Zymed, Invitrogen, South, San Francisco, CA), and calponin (clone CALP, DAKO Corporation, Carpinteria, CA). The monoclonal antibodies were used with the manufacturer's predilution. The labeled streptavidinbiotin system with peroxidase was utilized for detection. Expression was interpreted as positive when at least $5 \%$ of the tumor expressed the marker with at least weak intensity. Data were analyzed using a $\chi^{2}$ test to compare the proportion of expression between the different groups. A $P$-value of less than 0.05 was considered statistically significant.

\section{Results}

The male-to-female ratio in the cases of metastatic basal cell carcinomas was 9:1. The age at onset of primary tumor ranged from 30 to 67 years (median, 46 years). The age at onset for metastasis ranged from 34 to 72 years (median, 59 years). Six of the ten patients had undergone radiation therapy previously. The time to metastasis following radiation ranged from 2 to 13 years. The clinical features are summarized in Table 1.
Histologically, all but two of the metastatic basal cell carcinomas exhibited a nodular pattern with infiltrative cords of tumor at the edges. Of the remainder, one was mostly infiltrative and the other was nodular.

The findings of immunohistochemical studies are summarized in Table 2. Reduced actin expression in metastatic ( 3 of 10) as compared to infiltrative basal cell carcinoma (10 of 10) was a statistically significant difference $(P<0.05)$ (Figure 1). Interestingly, the metastatic basal cell carcinoma with predominantly infiltrative morphology was also actin negative. There was also a statistically significant difference $(P<0.05)$ between actin expression in nodular (3 of 12) and that in infiltrative basal cell carcinoma, with increased expression of actin in infiltrative as compared to nodular basal cell carcinomas. There was no statistically significant difference in actin expression in metastatic as compared to nodular basal cell carcinoma.

There was a statistically significant difference $(P<0.05)$ in expression of E-cadherin between metastatic basal cell carcinoma (10 of 10) as compared to nodular basal cell carcinoma (8 of 12), with increased expression of E-cadherin in metastatic basal cell carcinoma.

Differences in expression of calponin among the three types of basal cell carcinoma were not significant. None of the basal cell carcinoma subtypes were positive for myosin.

\section{Discussion}

Basal cell carcinoma remains the most common malignancy in Caucasian individuals, ${ }^{1}$ but despite

Table 1 Clinical features

\begin{tabular}{|c|c|c|c|c|}
\hline Age & $\operatorname{Sex}$ & Primary site, year & Metastatic site, year & History of radiation therapy \\
\hline 71 & Male & $\begin{array}{l}\text { Multiple: upper back and right } \\
\text { posterior arm, } 1993\end{array}$ & Left lung, 1997 & $\begin{array}{l}\text { Radiation to area of basal cell } \\
\text { carcinoma including axilla in } 1993\end{array}$ \\
\hline 72 & Male & $\begin{array}{l}\text { Multiple: left forearm, nose, arm, } \\
\text { chest, forehead, } 1997\end{array}$ & Femur, 2004 & $\begin{array}{l}\text { Radiation to face along with nitrogen } \\
\text { mustard for mycosis fungoides in } \\
\text { the } 1970 \text { s }\end{array}$ \\
\hline 34 & Male & $\begin{array}{l}\text { Multiple: scalp, 2000; } \\
\text { left neck, } 2004\end{array}$ & Cervical soft tissue, 2004 & No \\
\hline 64 & Female & Right scapula, 1979 & Right axilla and neck, 1984 & No \\
\hline 53 & Male & $\begin{array}{l}\text { Multiple: right ear, shoulder and } \\
\text { neck, } 1995\end{array}$ & $\begin{array}{l}\text { Right parotid and intraparotid } \\
\text { lymph node, } 2004\end{array}$ & Radiation to right ear and neck in 1995 \\
\hline 59 & Male & $\begin{array}{l}\text { Multiple: left shoulder, neck, } \\
\text { eyebrow, chest, oldest } 1982\end{array}$ & Bilateral axilla, mediastinum, 2005 & $\begin{array}{l}\text { Radiation to scalp and neck for tinea in } \\
1952\end{array}$ \\
\hline 42 & Male & $\begin{array}{l}\text { Multiple: chest wall, left posterior } \\
\text { leg, remote history as per patient }\end{array}$ & $\begin{array}{l}\text { Left inguinal lymph nodes and soft } \\
\text { tissue, } 2002\end{array}$ & No \\
\hline 90 & Male & $\begin{array}{l}\text { Multiple: face, inguinal crease, } \\
\text { 2005; perineum, } 2005\end{array}$ & Thoracic spine, 2007 & Radiation to face, 1992 \\
\hline 79 & Male & Right axilla, 2003 & Right upper lobe of lung, 2007 & Radiation to axilla, 2003 \\
\hline 77 & Male & $\begin{array}{l}\text { Multiple: scalp and ear, } 1995 \text { and } \\
\text { 2004, respectively }\end{array}$ & $\begin{array}{l}\text { Left neck dermis and subcutaneous } \\
\text { tissue, } 2007\end{array}$ & No \\
\hline
\end{tabular}

Mean age at metastasis $=56.4$ years.

Median age at metastasis $=59$ years.

Male-to-female ratio $=6: 1$ 
Table 2 Expression of actin, calponin, E-cadherin, and myosin

\begin{tabular}{lccc}
\hline $\begin{array}{l}\text { Immunohistochemical } \\
\text { marker }\end{array}$ & $\begin{array}{c}\text { Metastatic basal cell carcinoma } \\
\text { (number of positive cases) } \\
\text { number of cases) }\end{array}$ & $\begin{array}{c}\text { Nodular basal cell carcinoma } \\
\text { (number of positive cases/ } \\
\text { number of cases) }\end{array}$ & $\begin{array}{c}\text { Infiltrative basal cell carcinoma } \\
\text { (number of positive case/ } \\
\text { number of cases) }\end{array}$ \\
\hline Smooth muscle actin $^{\mathrm{a}}$ & $3 / 10$ & $3 / 12$ & $10 / 10$ \\
Calponin & $3 / 10$ & $6 / 12$ & $6 / 10$ \\
E-cadherin & $10 / 10$ & $8 / 12$ & $7 / 10$ \\
Myosin & $0 / 9$ & $0 / 12$ & $0 / 10$
\end{tabular}

${ }^{a}$ Statistically significant difference between actin expression in metastatic vs infiltrative and nodular vs infiltrative basal cell carcinoma $(P<0.05)$.

${ }^{\mathrm{b}}$ Statistically significant difference between E-cadherin expression in metastatic vs nodular basal cell carcinoma $(P<0.05)$.
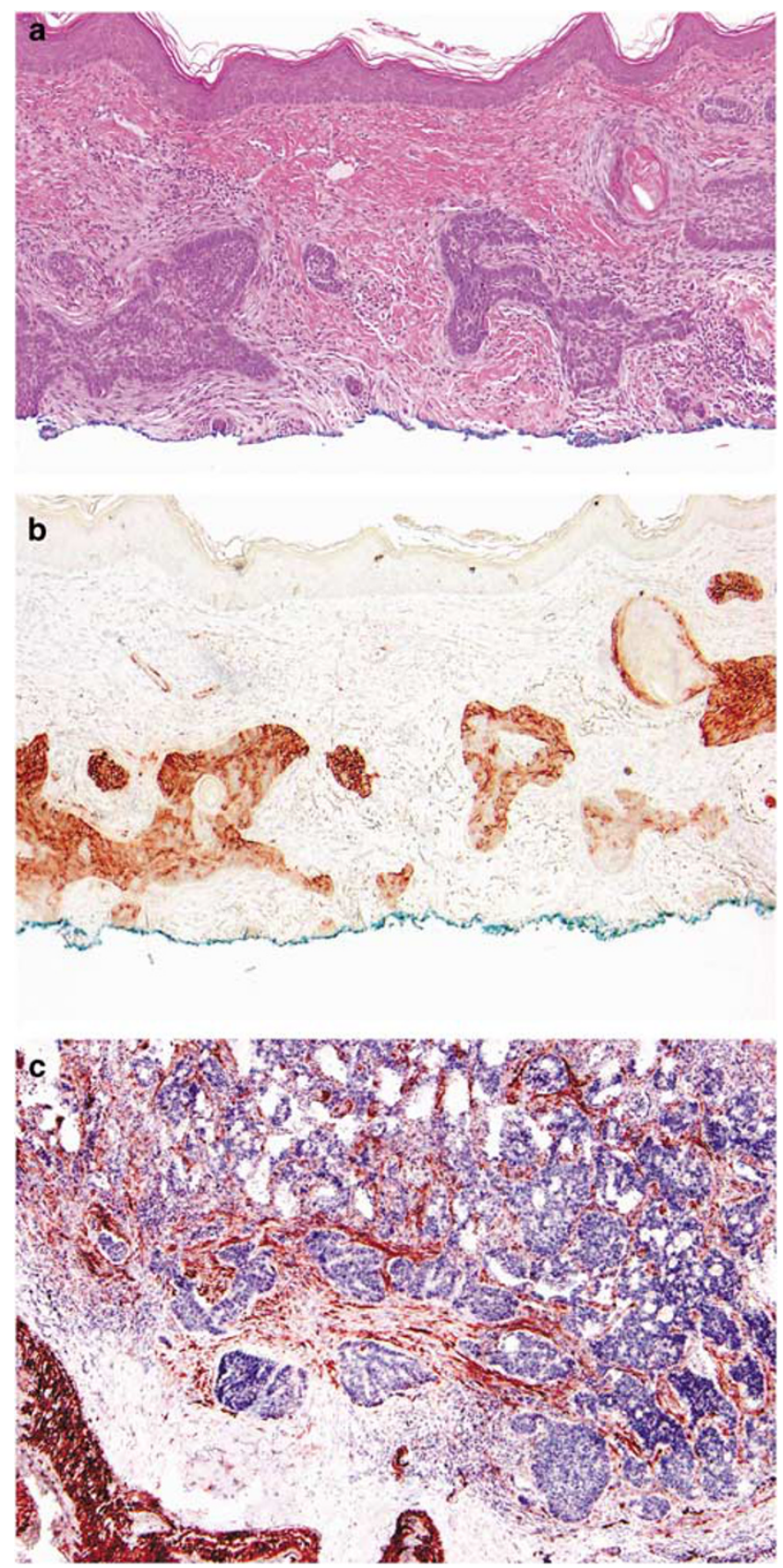

Figure 1 Loss of actin expression in metastatic basal cell carcinoma (panel $\mathbf{c}, \times 100$ ) as compared to infiltrative basal cell carcinoma (panel a, hematoxylin and eosin, $\times 100$; panel b, reactivity for actin, $\times 100$ ). its high incidence, metastatic basal cell is extremely rare, with the most recent studies suggesting that the rate is approximately $0.03 \%$ (ref. 2). In our study, we examined seven cases of metastatic basal cell carcinoma and the expression of actin, myosin, calponin, and E-cadherin as compared to nodular and infiltrative basal cell carcinoma.

Cytoskeletal reorganizations, especially alterations of contractile tension generated by the actin-myosin complex, are of central importance in the development of the phenotype of morphologically transformed neoplastic cells with invasive behavior. Microfilaments, which are composed primarily of actin, are largely responsible for cell motility and are only sparsely found in normal epithelial cells. ${ }^{9}$ Studies suggest that altered expression of actin may influence the invasive potential of tumors. ${ }^{7}$ Actin is a highly preserved protein and a major component of the microfilaments controlling cell morphology and motility. In the skin, alpha-smooth muscle actin has been identified within the erector pili muscle, fibroblasts of the tissue sheath surrounding anagen hair follicles, myoepithelial cells encompassing eccrine glands, pericytes around blood vessels, and vascular smooth muscle. It has been shown that an alteration in the staining pattern of intracellular microfilaments may occur with malignant transformation of some carcinomas. ${ }^{8}$ Actin has been found to be more prominently expressed in the tumor cells of the more aggressive subtypes of basal cell carcinoma. ${ }^{6,9}$ It may therefore be hypothesized that increased contractile proteins in human cancer cells may be related to the increased motility of these cells, and hence to their invasiveness and potential for metastasis.

Our finding of decreased actin expression in metastatic basal cell carcinoma as compared to infiltrative basal cell carcinoma supports the notion that although actin expression may be necessary for local invasiveness, it may not be essential for metastasis.

Calponin may also be involved in the regulation of the contractility of cells and cell motility. Calponin is an actin-linked protein, regulating actin-myosin interaction, and was originally purified from smooth muscle tissue. It has three isoforms that are categorized as basic, neutral, and acidic. Calponin 
may also be involved in the regulation of both contractility and the cytoskeletal structure and function. ${ }^{11}$ It is reasonable to presume that basal cell carcinoma cells that express calponin might acquire the myoepithelium-like contractile feature seen in myoepithelial cells around the secretory portion of the eccrine apparatus and hence enhance their invasiveness. ${ }^{10}$ Lee et $a l^{10}$ showed that calponin was more prevalent in mixed nodular-infiltrative or infiltrative basal cell carcinoma than in nodular basal cell carcinoma, and suggested that alpha-smooth muscle actin staining may be useful as a screening tool for infiltrative basal cell carcinoma lesions and that calponin may be a more specific indicator of infiltrative basal cell carcinoma and may also be implicated as having a role in metastatic basal cell carcinoma. However, we were not able to show a statistically significant difference in the expression of calponin among the different basal cell carcinoma subtypes.

E-cadherin expression was increased in metastatic basal cell carcinoma, as compared to both infiltrative and nodular basal cell carcinomas (however, the finding was statistically significant only in comparison to nodular basal cell carcinoma). This finding is surprising, as loss of E-cadherin is believed to be related to locally invasive and metastatic phenotypes and to poor prognosis in basal cell carcinoma; Pizarro et $a l^{12}$ have suggested that E-cadherin may be regarded as an invasion-suppression molecule.

Previous radiation therapy has been described earlier as a risk factor for metastatic basal cell carcinoma, ${ }^{4}$ and was a feature in six of the ten patients evaluated in this study. The time to metastasis following radiation in this study ranged from 4 to 13 years. Similar to previous demographics of metastatic basal cell carcinoma, the majority of patients were male, with a mean age of 56.4 years.

In summary, the observations made in this study suggest that a decreased expression of smooth muscle actin and an increased expression of E-cadherin may contribute to the metastatic potential of basal cell carcinomas. Further studies are indicated to understand the underlying mechanism for these observations.

\section{References}

1 Spates ST, Mellette R, Fitzpatrick J. Metastatic basal cell carcinoma. Dermatol Surg 2003;29:650-652.

2 Lo JS, Snow SN. Metastatic basal cell carcinoma: report of twelve cases with a review of the literature. J Am Acad Dermatol 1991;24:715-719.

3 Malone JP, Fedok FG. Basal cell carcinoma metastatic to the parotid: report of a new case and review of the literature. Ear Nose Throat J 2000;79:511-515.

4 Snow S, Saul WJ, Lo J, et al. Metastatic basal cell carcinoma: report of 5 cases. Cancer 1994;73: 328-335.

5 von Domarus H, Stevens PJ. Metastatic basal cell carcinoma. Report of five cases and review of 170 cases in the literature. J Am Acad Dermatol 1984;10:1043-1060.

6 Christian MM, Moy RL, Wagner RF, et al. A correlation of alpha-smooth muscle actin and invasion in micronodular basal cell carcinoma. Dermatol Surg 2001;27: 441-445.

7 Gabbiani G, Csank-Brassert J, Schneeberger J, et al. Contractile proteins in human cancer cells. Am J Pathol 1976;83:457-474.

8 Kitano Y. Distribution of actin filament in human malignant keratinocytes. Cell Biol Int Rep 1988;12:189-194.

9 Law AM, Oliveri CV, Pacheco-Quinto X, et al. Actin expression in purely nodular versus nodular-infiltrative basal cell carcinoma. J Cutan Pathol 2003;30: 232-236.

10 Lee MW, Ahn SJ, Choi JH, et al. Actin and calponin expression in basal cell carcinoma. Br J Dermatol 2004;151:934-936.

11 Werling RW, Hwang $\mathrm{H}$, Yaziji $\mathrm{H}$, et al. Immunohistochemical distinction of invasive from noninvasive breast lesions. A comparative study of p63 versus calponin and smooth muscle myosin heavy chain. Am J Surg Pathol 2003;27:82-90.

12 Pizarro A, Benito N, Navarro P, et al. E-cadherin expression in basal cell carcinoma. Br J Cancer 1994; 69:157-162. 